\title{
Lobaplatin arrests cell cycle progression in human hepatocellular carcinoma cells
}

\author{
Qiong Wu', Shu-Kui Qin², Feng-Meng Teng ${ }^{3}$, Chang-Jie Chen ${ }^{3}$, Rui Wang ${ }^{1}$
}

\begin{abstract}
Background: Hepatocellular carcinoma (HCC) still is a big burden for China. In recent years, the third-generation platinum compounds have been proposed as potential active agents for HCC. However, more experimental and clinical data are warranted to support the proposal. In the present study, the effect of lobaplatin was assessed in five HCC cell lines and the underlying molecular mechanisms in terms of cell cycle kinetics were explored.

Methods: Cytotoxicity of lobaplatin to human HCC cell lines was examined using MTT cell proliferation assay. Cell cycle distribution was determined by flow cytometry. Expression of cell cycle-regulated genes was examined at both the mRNA (RT-PCR) and protein (Western blot) levels. The phosphorylation status of cyclin-dependent kinases (CDKs) and retinoblastoma (Rb) protein was also examined using Western blot analysis.

Results: Lobaplatin inhibited proliferation of human HCC cells in a dose-dependent manner. For the most sensitive SMMC-7721 cells, lobaplatin arrested cell cycle progression in $G_{1}$ and $G_{2} / M$ phases time-dependently which might be associated with the down-regulation of cyclin B, CDK1, CDC25C, phosphorylated CDK1 (pCDK1), pCDK4, Rb, E2F, and $\mathrm{pRb}$, and the up-regulation of p53, p21, and p27.
\end{abstract}

Conclusion: Cytotoxicity of lobaplatin in human HCC cells might be due to its ability to arrest cell cycle progression which would contribute to the potential use of lobaplatin for the management of HCC.

\section{Background}

Hepatocellular carcinoma (HCC) is one of the most common cancers with poor prognosis. In China alone, more than 401,000 new patients were diagnosed with $\mathrm{HCC}$ and more than 371,000 patients died of this disease in 2008 [1]. The poor outcome of HCC is mainly due to it rarely presents with characteristic symptoms at early stage and over $80 \%$ of patients lose the chance of curative hepatectomy when the diagnosis of $\mathrm{HCC}$ was confirmed [2].

For the management of advanced HCC, systemic chemotherapy with classical cytotoxic agents offers a marginal survival benefit $[3,4]$. To improve the chemotherapeutic efficacy, a few of novel cytotoxic agents have been employed to treat patients with HCC. Oxaliplatin, a thirdgeneration platinum compound, has exhibited promising activity against advanced HCC with tolerable toxicity in phase II clinical trials [5,6]. Recently, a randomized

\footnotetext{
* Correspondence: qinsk@csco.org.cn

2Department of Oncology, the 81 Hospital of the Chinese People's

Liberation Army, Nanjing, China

Full list of author information is available at the end of the article
}

controlled phase III trial has been performed to evaluate the efficacy of FOLFOX4 (oxaliplatin plus 5-fluorouracil/ leucovorin) in Asian patients with advanced HCC. The data from first interim analysis have shown a significant advantage of FOLFOX4 over doxorubicin in terms of overall response rate (ORR), disease control rate (DCR), and time to progression (TTP) [7].

As another third-generation platinum compound, lobaplatin (D-19466; 1, 2-diammino-methyl-cyclobutaneplatinum(II)-lactate) has shown encouraging anti-cancer activity in a variety of tumor types without evident hepatotoxicity [8-10] and has been approved in China for the treatment of chronic myelogenous leukemia (CML), metastatic breast cancer and small cell lung cancer [11]. It is noteworthy that some tumors resistant to cisplatin are still sensitive to lobaplatin [8]. Base on these considerations, we speculate lobaplatin might be useful for advanced HCC patients but more experimental and clinical data are warranted. In the present study, the effect of lobaplatin was assessed in five human HCC cell lines and the underlying molecular mechanisms in terms of cell cycle kinetics were explored. 


\section{Materials and methods Cell culture}

Lobaplatin and oxaliplatin were purchased from Hainan Chang'an International Pharmaceutical (Hainan, China) and Sigma (St. Louis, MO, USA), respectively. The human HCC cell lines, SMMC-7721, Bel-7402, HepG2, and Huh7, were obtained from the Institute of Biochemistry and Cell Biology, Chinese Academy of Sciences (Shanghai, China). Hep 3B was kindly provided by Dr. X. Wang (Department of Oncology, Changzheng Hospital, Shanghai, China). All cell lines were maintained in Dulbecco's modified Eagle's medium (Gibco BRL, Carlsbad, CA, USA) supplemented with $10 \%$ fetal bovine serum (Gibco) at $37^{\circ} \mathrm{C}$ in a humidified atmosphere containing $5 \% \mathrm{CO}_{2}$.

\section{Proliferation assay}

Cytotoxicity of lobaplatin to human HCC cell lines was examined using cell proliferation assay. Cells were seeded in a 96-well microtiter plate at $5 \times 10^{3}$ cells/well, and cultured for 24 hours prior to exposure to lobaplatin or oxaliplatin of varying concentrations for 48 hours. Ten $\mu \mathrm{l}$ 3-(4, 5-dimethylthiazol-2-yl)-2, 5-diphenyltetrazolium bromide (MTT, $5 \mathrm{mg} / \mathrm{ml}$ ) in phosphate buffered saline (PBS) were then added to each well. Four hours later the culture media was discarded and the dark blue crystals were dissolved in $100 \mu \mathrm{l}$ dimethylsulfoxide (DMSO). The optical density (OD) was measured at $560 \mathrm{~nm}$ using a microplate reader (Thermo labsystems, Helsinki, Finland). Six wells were used for each concentration. The $50 \%$ inhibitory concentration $\left(\mathrm{IC}_{50}\right)$ was calculated by nonlinear regression fit of the mean values of the data obtained in triplicate independent experiments.

\section{Flow cytometric (FCM) analysis}

The effect of lobaplatin on human HCC cell cycle distribution was determined by FCM analysis. Cells were seeded in six-well plates at $5 \times 10^{5}$ cells/well and cultured for 24 hours prior to lobaplatin exposure for 0 , 24, 36 and 48 hours. Control cells received only solvent for the indicated time durations above. Cells were collected by trypsinization, washed twice with ice cold PBS, fixed in $70 \%$ ethanol, and stained with propidium iodide (PI; $5 \mu \mathrm{g} / \mathrm{ml}$ PI in PBS containing $0.1 \%$ Triton X-100 and $0.2 \mathrm{mg} / \mathrm{ml}$ RNase A) overnight at $4^{\circ} \mathrm{C}$ in the dark until analyzed using a FACScan flow cytometer (BD Biosciences, San Jose, CA, USA). Cell fluorescence was measured in duplicate at each time point and all experiments were performed in triplicate.

\section{Reverse transcription polymerase chain reaction (RT-PCR) analysis}

The mRNA expression of cell cycle-regulated genes was examined by RT-PCR. Total RNA was extracted using
Trizol solution (Invitrogen, Carlsbad, CA, USA). Singlestranded cDNAs were synthesized with oligo (dT) primers in a reaction starting with $2 \mu \mathrm{g}$ of total RNA using Superscript II reverse transcriptase (Fermentas Life Sciences, Hanover, MD, USA). PCR amplification was carried out in $25 \mu \mathrm{l}$ total volume containing: $2 \mu \mathrm{l}$ cDNA, $200 \mu \mathrm{M}$ each dNTP, 0.25 units Taq polymerase, and $1 \mu \mathrm{M}$ each primer (Sangon, Shanghai, China). Reaction conditions were optimized as follows: activation at $95^{\circ} \mathrm{C}$ for $5 \mathrm{~min}$, followed by $30-35$ cycles at $94^{\circ} \mathrm{C}$ for $45 \mathrm{~s}, 55-64^{\circ} \mathrm{C}$ for $45 \mathrm{~s}$, and $72^{\circ} \mathrm{C}$ for $1 \mathrm{~min}$. A series of calibration experiments verified that the conditions were within the exponential phase. The primers of cell cycle-regulated genes are listed in Table 1. The PCR product was analyzed by agarose gel electrophoresis and quantified using an image analyzer (Bio-Rad, Hercules, CA, USA). The result was verified in three independent experiments.

\section{Western blot analysis}

The protein expression of cell cycle-regulated genes was examined by Western blot. Cell extract was prepared using a non-denaturing lysis buffer. Protein concentration was determined using a Bio-Rad detergent-compatible protein assay kit (Bio-Rad). Samples (50-70 $\mu \mathrm{g}$ protein) were denatured in $5 \times$ SDS-PAGE loading buffer and separated in $10 \%$ SDS-PAGE gels. The proteins were electro-transferred to nitrocellulose membranes followed by blocking with $5 \%(\mathrm{w} / \mathrm{v})$ non-fat dry milk in Tris-buffered saline for 2 hours at room temperature. Membrane was probed with primary antibody at 1:400 dilution for 2 hours at room temperature and then washed three times with $0.1 \%$ Tween $20 / \mathrm{PBS}$ prior to incubation with an appropriate secondary antibody conjugated with peroxidase (Santa Cruz Biotechnology, Santa Cruz, CA, USA) for 1.5 hour. Signal detection was conducted using the enhanced chemiluminescence detection system (Bio-Rad). The blots shown are representative of three independent experiments. The primary antibodies to cyclin B, cyclin D1, CDK1, CDK4, CDK6, CDC25C, p53, p16, p21, p27, Rb, E2F, and GAPDH were purchased from Santa Cruz Biotechnology. To determine the levels of phosphorylated CDKs (pCDKs) and retinoblastoma $(\mathrm{pRb})$ protein, the phospho-specific antibodies (Santa Cruz Biotechnology) targeting pCDK1 (Tyr15), pCDK4 (Tyr15), and pRb (Ser780) were used.

\section{Results}

\section{Lobaplatin inhibited proliferation of human HCC cells}

As shown in Figure 1A, lobaplatin inhibited cell proliferation of cultured human HCC cell lines with the $\mathrm{IC}_{50}$ values $(48 \mathrm{~h}$ ) ranging from 1.45 to $5.22 \mu \mathrm{g} / \mathrm{ml}$. The rank order of sensitivity was p53 wild-type SMMC-7721 > Bel-7402 > p53 null Hep 3B > p53 mutant Huh-7. 
Table 1 Primers for RT-PCR analysis

\begin{tabular}{lll}
\hline Gene & Forward primer & Reverse primer \\
\hline cyclin B & GCACTTCCTCCTCCTCAA & CTTCGATGTGGCCATCTTG \\
cyclin D1 & CTGTGCTGCGAAGTGGAACCAT & TTCATGGCCAGCGGGAAGACCTC \\
CDK1 & GATTCTATCCCTCCTGGTC & TAGGCTTCCTGGTTCC \\
CDK4 & CTGAGAATGGCTACCTCTCGATATG & AGAGTGTAACAACCACGGGTGTAAG \\
CDK6 & CCGAGTAGTGCATCGCGATCTAA & CTTGCCTAGTCATCGATATC \\
CDC25C & GAACAGGCCAAGGCTGAAGC & GCCCCTGGTAGAATCTCC \\
p53 & GAGGCGCTGCCCCCACCATGA & AGCTCTCGGAACATCTCGAAGC \\
p16 & AGCCTTCGGCTGACTGGCTGG & CTGCCCATCATCATGACCTGG \\
p21 & ATGTCAGAACCGGCTGGGATGTC \\
P27 & CCTAGGCTTCCTCCTGGAGGAGAT & TITGGGGAACCGTCTGAAAC \\
\hline
\end{tabular}

The p53 wild-type HepG2 cell line showed a similar sensitivity to lobaplatin as the Huh-7 cells. In addition, lobaplatin appeared to have similar cytotoxicity profiles to oxaliplatin in these human HCC cell lines.

The dose-response curve of lobaplatin in SMMC-7721 cells was specially shown in Figure $1 \mathrm{~B}$. In a range of 0.25 to $4.5 \mu \mathrm{g} / \mathrm{ml}$, lobaplatin inhibited cell proliferation of SMMC-7721 cells in a dose-dependent manner. The $\mathrm{IC}_{50}$ value of $1.45 \mu \mathrm{g} / \mathrm{ml}$ was chosen as a working

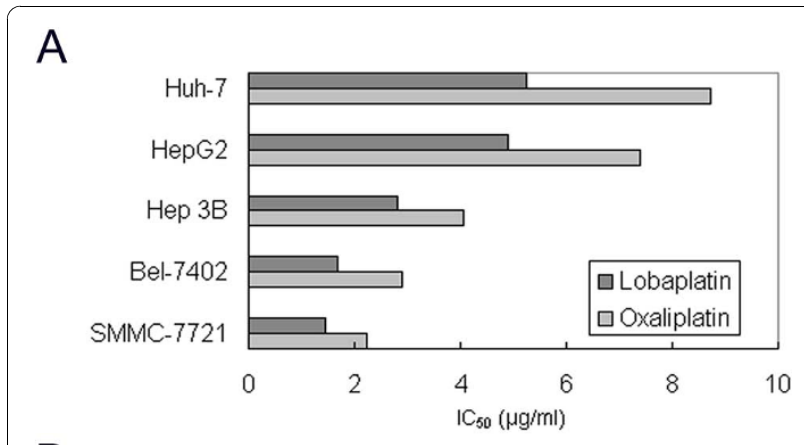

B

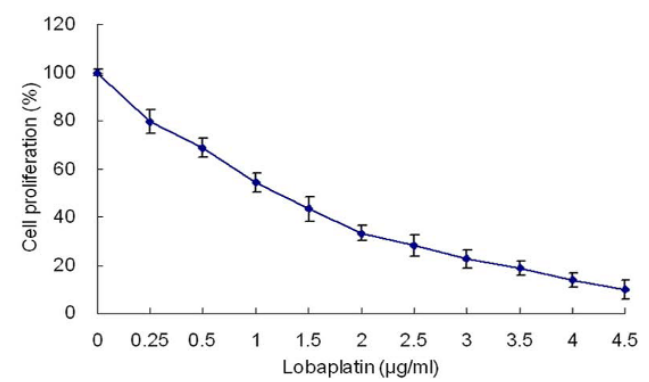

Figure 1 Lobaplatin inhibited proliferation of human HCC cells. (A) A comparison of lobaplatin and oxaliplatin in five human HCC cell lines. The $I_{50}$ value was determined using cell proliferation assay. (B) The dose-response curve of lobaplatin in SMMC-7721 cells. The cell proliferation rate of untreated cells was defined as $100 \%$ and that of treated cells was expressed as a percentage of the untreated cells. The data represented the mean \pm standard deviations of three independent experiments. concentration for subsequent cell cycle experiments in SMMC-7721 cells.

Lobaplatin arrested cell cycle progression in $G_{1}$ and $G_{2} / M$ phases time-dependently

The effect of lobaplatin on cell cycle distribution of SMMC-7721 cells was shown in Figure 2. After adjustment with their corresponding controls, the proportions of $G_{1}, S$, and $G_{2} / M$ phases in cells treated with lobaplatin were $45.31,22.88$, and $31.81 \%$ at $0 \mathrm{~h}, 59.91,11.92$, and $28.17 \%$ at $24 \mathrm{~h}, 56.89,2.83$, and $40.28 \%$ at $36 \mathrm{~h}$, and $53.80,2.07$, and $44.13 \%$ at $48 \mathrm{~h}$, respectively. Under the induction of lobaplatin, accumulation of cells in $G_{1}$ phase occurred from 24 to $48 \mathrm{~h}$ and $\mathrm{G}_{2} / \mathrm{M}$ phase arrest appeared from 36 to $48 \mathrm{~h}$. A concurrent reduction of

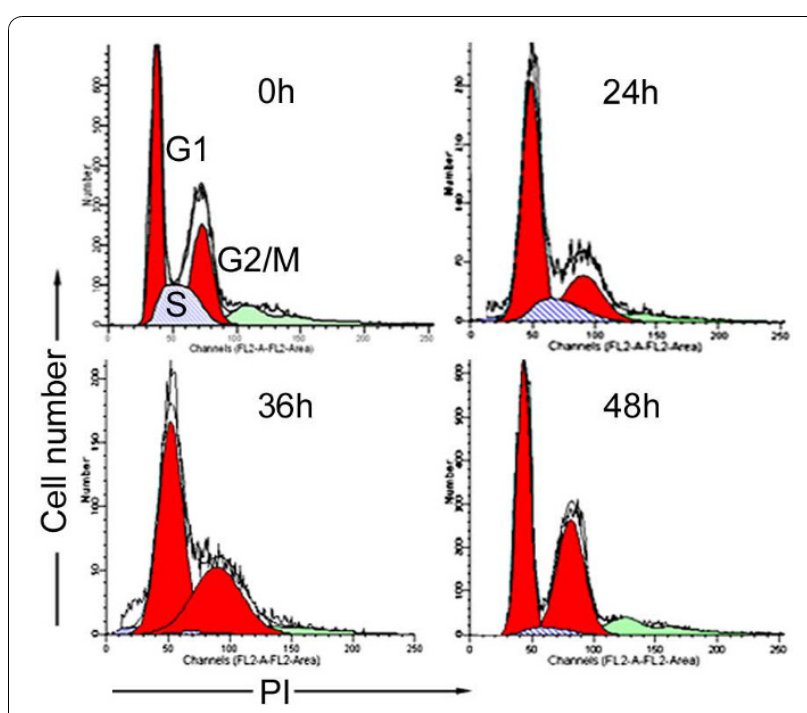

Figure 2 Lobaplatin arrested cell cycle progression in $G_{1}$ and $\mathrm{G}_{2} / \mathbf{M}$ phases time-dependently. SMMC-7721 cells were treated with $1.45 \mu \mathrm{g} / \mathrm{ml}$ lobaplatin. In the course of treatment, cell cycle distribution was analyzed by FCM at $0,24,36$, and $48 \mathrm{~h}$. The profiles showed dual-variable plots of cell number versus PI uptake. $G_{1}, S$, and $G_{2} / M$ cell populations were quantified. 
the cell population in S phase was observed. These data suggested that lobaplatin could arrest cell cycle progression in $G_{1}$ and $G_{2} / M$ phases time-dependently.

\section{Lobaplatin down-regulated cyclin B, CDK1, CDC25C, pCDK1, and pCDK4}

As shown in Figure 3A and Table 2, the mRNA levels of cyclin $B, C D K 1$, and $C D C 25 C$ phosphatase were moderately repressed at $24 \mathrm{~h}$ after lobaplatin treatment and significantly down-regulated at 36 and $48 \mathrm{~h}$ (changes > 2 -fold). Meanwhile, the mRNA levels of cyclin D1, $C D K 4$, and CDK6 were slightly enhanced or inhibited but the changes less than 2-fold compared to their controls. Lobaplatin did not appear to affect the mRNA levels of cyclin D1, CDK4, and CDK6.

The protein expression of genes mentioned above was generally consistent with the mRNA expression. As shown in Figure $3 \mathrm{~B}$ and Table 3, the fold changes of genes at the mRNA level were further confirmed by the protein level.

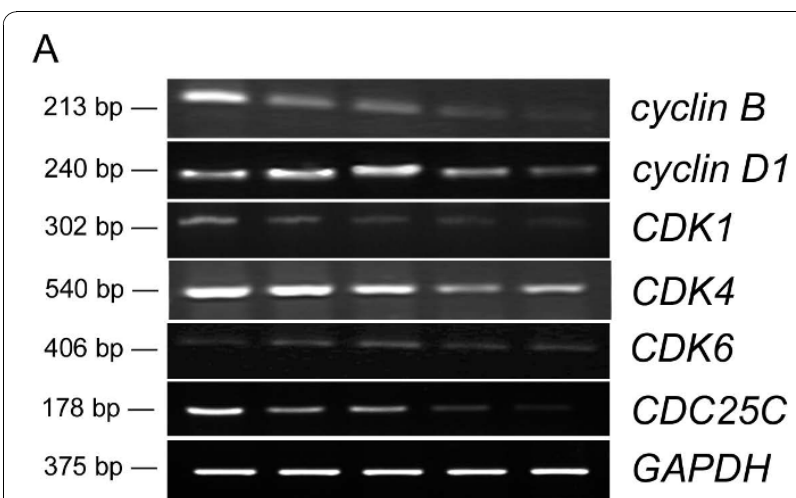

B

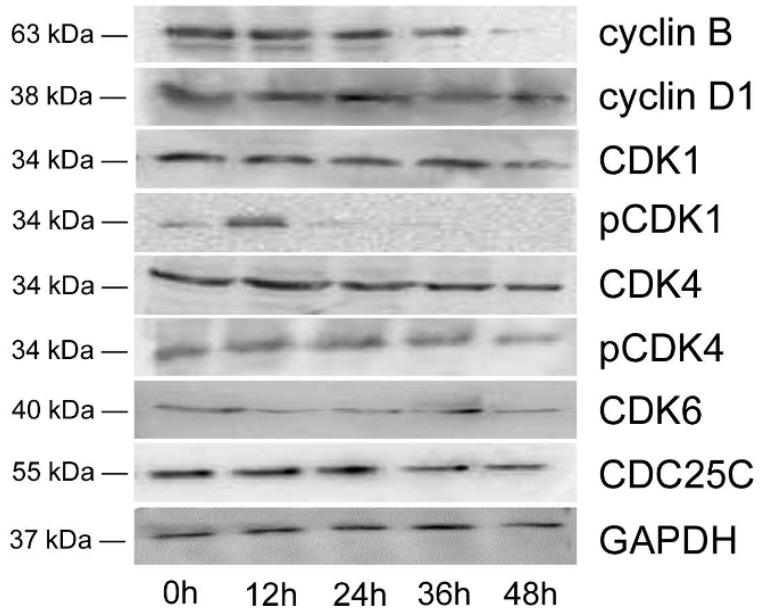

Figure 3 Lobaplatin down-regulated cyclin B, CDK1, CDC25C, pCDK1, and pCDK4. Expression of cell cycle-regulated genes was determined at $0,12,24,36$, and $48 \mathrm{~h}$ in SMMC-7721 cells after 1.45 $\mu \mathrm{g} / \mathrm{ml}$ lobaplatin treatment. GAPDH as a control. (A) The mRNA level. (B) The protein level.
Moreover, lobaplatin could regulate the phosphorylation status of CDKs and significantly reduce both pCDK1 after $24 \mathrm{~h}$ of treatment and pCDK4 after $36 \mathrm{~h}$.

Lobaplatin up-regulated p53, p21, and p27

The effect of lobaplatin on p53 and CDK inhibitors (p16, $\mathrm{p} 21$, and $\mathrm{p} 27$ ) was subsequently examined at both the mRNA and protein levels (Figure 4, Table 2, 3). The results indicated that the expression of p53 was significantly increased within $24 \mathrm{~h}$ after lobaplatin treatment and p27 was up-regulated at somewhat later time points. The expression of p21 continued to be up-regulated and reached a peak of 7 -fold increase at $36 \mathrm{~h}$ at the protein level. No significant change of p16 was found after lobaplatin treatment.

\section{Lobaplatin down-regulated $\mathrm{Rb}, \mathrm{E} 2 \mathrm{~F}$, and $\mathrm{pRb}$}

During the lobaplatin treatment, the significant downregulation of $\mathrm{Rb}$ appeared at $24 \mathrm{~h}$ followed by a persistent low level while its phosphorylation status ( $\mathrm{pRb}$ ) was significantly reduced in the late course of treatment. E2F also became significantly down-regulated after $36 \mathrm{~h}$ of lobaplatin treatment (Figure 5 and Table 3).

\section{Discussion}

The present study aimed at evaluating cytotoxicity of lobaplatin in human HCC cells in vitro. Among the five human HCC cell lines used, SMMC-7721 was the most sensitive one to lobaplatin and hence was selected as the cell model to reveal the underlying cytotoxic mechanisms of lobaplatin in terms of cell cycle kinetics. The results suggested that (i) lobaplatin could inhibit the proliferation of human HCC cells through arresting cell cycle progression in $G_{1}$ and $G_{2} / M$ phases; (ii) The cell cycle arrest on human HCC cells induced by lobaplatin might be associated with the down-regulation of CDK1/ cyclin $\mathrm{B}$ and $\mathrm{Rb} / \mathrm{E} 2 \mathrm{~F}$ complexes and the up-regulation of CDK inhibitors.

Lobaplatin has shown favorable activity in various types of cancers including breast, oesophageal, lung, and ovarian cancers as well as CML [8]. In this study, lobaplatin exhibited evident cytotoxicity to human HCC cells. Interestingly, the p53 wild-type SMMC-7721 and Bel-7402 were the most sensitive cell lines to lobaplatin than Huh-7 which was p53 mutant. It indicates an important role for p53 phenotype in response to lobaplatin. However, the fact that p53 wild-type HepG2 cell line was resistant to lobaplatin suggests p53 phenotype is not the sole determinants of sensitivity to lobaplatin for human HCC cells. Moreover, characterized by p53 phenotype in these HCC cell lines, lobaplatin appeared to have similar cytotoxicity profiles to oxaliplatin which was active for advanced HCC patients $[5,6]$. The results indicate that lobaplatin may have potential value for the management of human HCC. 
Table 2 Genes/GAPDH ratio at the mRNA level (The densitometric data are presented as fold changes as compared with their corresponding controls)

\begin{tabular}{lllllllllll}
\hline Treatment time & cyclin B & cyclin D1 & CDK1 & CDK4 & CDK6 & CDC25C & P53 & p16 & p21 & p27 \\
\hline $0 \mathrm{~h}$ & 1 & 1 & 1 & 1 & 1 & 1 & 1 & 1 & 1 & 1 \\
$12 \mathrm{~h}$ & 0.89 & 1.47 & 0.83 & 1.21 & 1.10 & 0.51 & 3.03 & 1.22 & 2.05 & 1.26 \\
$24 \mathrm{~h}$ & 0.53 & 1.36 & 0.53 & 0.95 & 1.14 & 0.54 & 2.69 & 1.85 & 2.50 & 1.32 \\
$36 \mathrm{~h}$ & 0.18 & 0.87 & 0.25 & 0.52 & 1.18 & 0.21 & 1.30 & 1.59 & 3.14 & 2.05 \\
$48 \mathrm{~h}$ & 0.09 & 0.59 & 0.13 & 0.53 & 1.04 & 0.12 & 0.79 & 1.77 & 3.64 & 1.95 \\
\hline
\end{tabular}

From the viewpoint of cell cycle, cytotoxicity of lobaplatin might be due to its ability to arrest cell cycle progression in our study. Upon incubation with lobaplatin, SMMC-7721 cells were continuously arrested in $G_{1}$ phase after $24 \mathrm{~h}$ of treatment. It is well known that the complexes of CDK4, 6/cyclin D play an important role in $\mathrm{G}_{1}-\mathrm{S}$ transition by phosphorylating $\mathrm{Rb}[12,13]$. As a consequence of $\mathrm{Rb}$ phosphorylation, E2F is released from the $\mathrm{Rb} / \mathrm{E} 2 \mathrm{~F}$ complex, thereby activating the expression of the genes that are required for $S$ phase transition [14]. Our results showed that the expression of CDK4, 6/cyclin D1 complexes was not affected by lobaplatin. Thus, there may be other mechanisms contributed to $G_{1}$ phase arrest in this study. For the reason that the activity of CDKs is negatively controlled by binding CDK inhibitors to CDK/cyclin complexes [15], we examined the expression of CDK inhibitors both at the mRNA and protein levels. The results indicated that lobaplatin drastically enhanced the expression of p21 and p27, suggesting that CDKs activity may be inhibited by these two CDK inhibitors. Furthermore, lobaplatin down-regulated the expression of Rb/E2F complex and consequently inhibited the expression of E2F target genes. Meanwhile, the changes of $\mathrm{pCDK} 4$ and $\mathrm{pRb}$ were revealed in accordance with this cell cycle variation.

The cell cycle analysis in this study revealed a prominent $G_{2} / M$ phase arrest in the late course of lobaplatin treatment. $G_{2}-M$ transition is partly governed by the activity of CDK1, which is positively regulated by cyclin $\mathrm{B}$ [16]. CDK1 activation is also controlled by dephosphorylation at Tyr15 by CDC25C phosphatase $[16,17]$. Lobaplatin significantly down-regulated cyclin B, CDK1, and $\mathrm{CDC} 25 \mathrm{C}$ as well as pCDK1. Absence of cyclin B and CDK1 after $36 \mathrm{~h}$ of treatment might have contributed to
$\mathrm{G}_{2} / \mathrm{M}$ phase arrest as a late event. The reduced expression of CDC25C may have contributed to the lower CDK1 activity.

As an essential cell cycle regulator, the p53 tumor suppressor plays an important role in the cellular response to platinum agents. For example, 1,2-diaminocyclohexane-acetato-Pt could arrest the wild-type p53 cells in $G_{1}$ phase and the mutant p53 cells in $\mathrm{G}_{2} / \mathrm{M}$ phase in ovarian cancer [18]. P53 transcriptionally activates a series of genes involved in both $G_{1}-S$ and $G_{2}-M$ transitions in response to genotoxic stress $[19,20]$. Among these genes, p21 is a well-established negative regulator of $\mathrm{G}_{1}-\mathrm{S}$ transition [19]. It also inhibits the CDK1/cyclin B complex and keeps $G_{2}$ arrest maintenance [20]. In the present study, lobaplatin induced a rapid accumulation of p53 which occurred within 24 h of lobaplatin treatment. Consistent with this finding, p21 was strongly up-regulated with a 7 -fold increase at $36 \mathrm{~h}$ after lobaplatin treatment. The data suggest that the p53-p21 pathway may contribute to $G_{1}$ and $G_{2} / M$ cell cycle arrests in this p53 wildtype SMMC-7721 cells [21,22].

Being similar to cisplatin, lobaplatin induces intra-strand DNA-Pt crosslinks [23] but somewhat less efficiently [24]. Lobaplatin shows incomplete cross-resistance with cisplatin [23] which suggest the former might have an underlying action mechanism different from the latter. Cisplatin can reduce the DNA synthesis rate with a subsequent accumulation in $S$ phase followed by $G_{2} / M$ phase arrest [25-27]. The results in our study lobaplatin arrested SMMC-7721 cells in $G_{1}$ and $G_{2} / M$ phases demonstrate the existence of a different action mechanism of lobaplatin. Oxaliplatin, another third-generation platinum compound, could activate $G_{1}-S$ checkpoint and block $G_{2}-M$ transition completely in p53 wild-type HCT-116 colon

Table 3 Genes/GAPDH ratio at the protein level (The densitometric data are presented as fold changes as compared with their corresponding controls)

\begin{tabular}{|c|c|c|c|c|c|c|c|c|c|c|c|c|c|c|c|}
\hline Treatment time & cyclin B & cyclin D1 & CDK1 & pCDK1 & CDK4 & pCDK4 & CDK6 & CDC25C & p53 & p16 & p21 & p27 & E2F & $\mathbf{R b}$ & $\mathrm{pRb}$ \\
\hline $\mathrm{Oh}$ & 1 & 1 & 1 & 1 & 1 & 1 & 1 & 1 & 1 & 1 & 1 & 1 & 1 & 1 & 1 \\
\hline $12 \mathrm{~h}$ & 0.94 & 1.17 & 0.79 & 1.50 & 1.15 & 0.75 & 1.21 & 1.25 & 4.16 & 0.87 & 2.15 & 1.58 & 1.14 & 0.98 & 1.01 \\
\hline $24 \mathrm{~h}$ & 0.47 & 1.28 & 0.59 & 0.39 & 0.95 & 0.51 & 1.04 & 1.58 & 2.41 & 1.66 & 5.32 & 2.04 & 0.81 & 0.39 & 0.55 \\
\hline $36 h$ & 0.26 & 0.77 & 0.23 & 0.15 & 0.56 & 0.36 & 1.11 & 0.63 & 1.57 & 1.39 & 7.00 & 3.00 & 0.46 & 0.45 & 0.29 \\
\hline $48 \mathrm{~h}$ & 0.07 & 0.64 & 0.09 & 0.02 & 0.65 & 0.19 & 1.19 & 0.47 & 0.63 & 1.74 & 5.63 & 1.96 & 0.40 & 0.39 & 0.34 \\
\hline
\end{tabular}




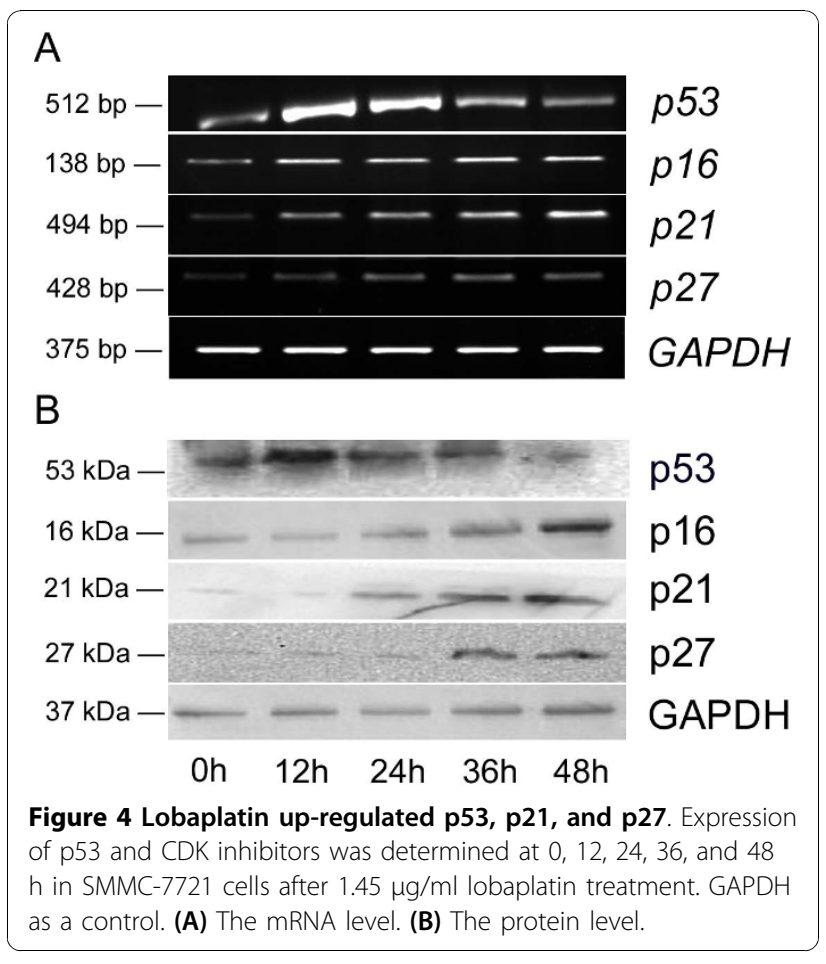

carcinoma cells [28]. As revealed in this study, the effect of lobaplatin on cell cycle seems similar to that of oxaliplatin. Further studies should be conducted to examine whether the effect of lobaplatin on $\mathrm{G}_{1}-\mathrm{S}$ transition is associated with its incomplete cross-resistance with cisplatin.

In conclusion, the present study demonstrated the encouraging efficacy of lobaplatin against human HCC in vitro. Lobaplatin could arrest cell cycle in $G_{1}$ and $G_{2}$ / $M$ phases which was possibly associated with the downregulation of cyclin $\mathrm{B}, \mathrm{CDK} 1, \mathrm{CDC} 25 \mathrm{C}, \mathrm{pCDK} 1$, $\mathrm{pCDK} 4, \mathrm{Rb}, \mathrm{E} 2 \mathrm{~F}$, and $\mathrm{pRb}$, and up-regulation of $\mathrm{p} 53$, p21, and p27. These alterations of cell cycle kinetics might contribute to a better understanding for cytotoxicity of lobaplatin and facilitate its potential use for the management of $\mathrm{HCC}$.

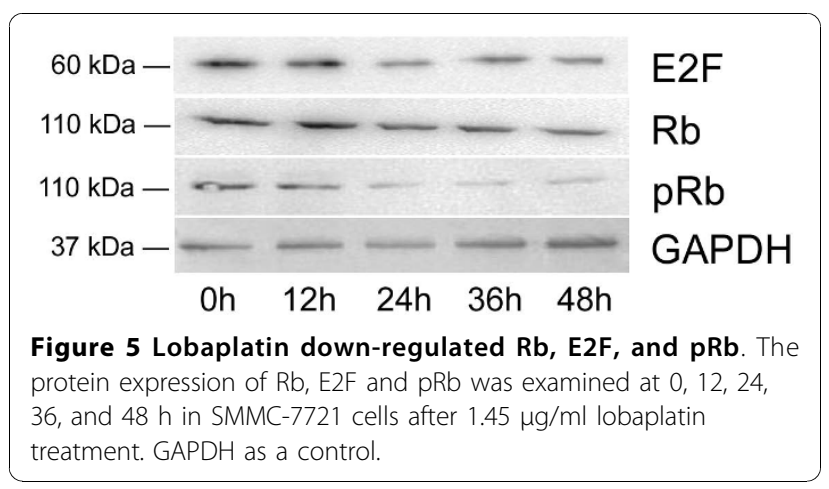

\section{Acknowledgements}

This study was supported by the National High Technology Research and Development Program of China (863 Program; \#2006AA020608). We thank Hui Wang for excellent technical assistance in cell culture.

\section{Author details}

'Department of Medical Oncology, Affiliated Hospital of Bengbu Medical College, Bengbu, Anhui, China. ${ }^{2}$ Department of Oncology, the 81 Hospital of the Chinese People's Liberation Army, Nanjing, China. ${ }^{3}$ Department of Laboratory Medicine, Bengbu Medical College, Bengbu, Anhui, China.

\section{Authors' contributions}

QW and SKQ were responsible for research design and manuscript preparing. FMT, CJC, and RW performed the experiments and analyzed the data. All authors have read and approved the final manuscript.

\section{Competing interests}

The authors declare that they have no competing interests.

Received: 27 July 2010 Accepted: 31 October 2010 Published: 31 October 2010

\section{References}

1. Ferlay J, Shin HR, Bray F, Forman D, Mathers C, Parkin DM: GLOBOCAN 2008, Cancer Incidence and Mortality Worldwide: IARC CancerBase No. 10 [Internet]. Lyon, France: International Agency for Research on Cancer 2010 [http://globocan.iarc.fr].

2. Hung H: Treatment modalities for hepatocellular carcinoma. Curr Cancer Drug Targets 2005, 5:131-138.

3. Bruix J, Sherman M, Llovet JM, Beaugrand M, Lencioni R, Burroughs AK, Christensen E, Pagliaro L, Colombo M, Rodés J, EASL Panel of Experts on HCC: Clinical management of hepatocellular carcinoma. Conclusions of the Barcelona-2000 EASL conference. European Association for the Study of the Liver. J Hepatol 2001, 35:421-430.

4. Thomas MB, O'Beirne JP, Furuse J, Chan AT, Abou-Alfa G, Johnson P: Systemic therapy for hepatocellular carcinoma: cytotoxic chemotherapy, targeted therapy and immunotherapy. Ann Surg Oncol 2008, 15:1008-1014.

5. Louafi S, Boige V, Ducreux M, Bonyhay L, Mansourbakht T, de Baere T, Asnacios A, Hannoun L, Poynard T, Taïeb J: Gemcitabine plus oxaliplatin (GEMOX) in patients with advanced hepatocellular carcinoma (HCC): results of a phase II study. Cancer 2007, 109:1384-1390.

6. Boige V, Raoul JL, Pignon JP, Bouché O, Blanc JF, Dahan L, Jouve JL, Dupouy N, Ducreux M, Fédération Francophone de Cancérologie Digestive: Multicentre phase II trial of capecitabine plus oxaliplatin (XELOX) in patients with advanced hepatocellular carcinoma: FFCD 03-03 trial. $B r$ J Cancer 2007, 97:862-867.

7. Qin S, Bai Y, Ye S, Fan J, Lim H, Cho JY, Thongprasert S, Chao Y, Rau K, Sun Y: Phase III study of oxaliplatin plus 5 -fluorouracil/leucovorin (FOLFOX4) versus doxorubicin as palliative systemic chemotherapy in advanced HCC in Asian patients [meeting abstract]. J Clin Oncol 2010, 28:4008.

8. McKeage MJ: Lobaplatin: a new antitumour platinum drug. Expert Opin Investig Drugs 2001, 10:119-128.

9. Gietema JA, de Vries EG, Sleijfer DT, Willemse PH, Guchelaar HJ, Uges DR, Aulenbacher P, Voegeli R, Mulder NH: A phase I study of 1,2diamminomethyl-cyclobutane-platinum (II)-lactate (D-19466; lobaplatin) administered daily for 5 days. Br J Cancer 1993, 67:396-401.

10. Fiebig HH, Hens H, Mross K: Phase I clinical trial of lobaplatin (D-19466) after intravenous bolus injection. Onkologie 1994, 17:142-148.

11. State Food and Drug Administration Database. [http://app1.sfda.gov.cn/ datasearch/face3/base.jsp].

12. Deshpande A, Sicinski P, Hinds PW: Cyclins and cdks in development and cancer: a perspective. Oncogene 2005, 24:2909-2915.

13. Coqueret O: Linking cyclins to transcriptional control. Gene 2002, 299:35-55.

14. Harbour JW, Dean DC: The Rb/E2F pathway: expanding roles and emerging paradigms. Genes Dev 2000, 14:2393-2409.

15. Sherr CJ, Roberts JM: Inhibitors of mammalian G1 cyclin-dependent kinases. Genes Dev 1995, 9:1149-1163. 
16. O'Connor PM: Mammalian G1and G2 phase checkpoints. Cancer Surv 1997, 29:151-182.

17. Nurse P: Universal control mechanism regulating onset of M-phase. Nature 1990, 344:503-508.

18. Hagopian GS, Mills GB, Khokhar AR, Bast RC Jr, Siddik ZH: Expression of p53 in cisplatin-resistant ovarian cancer cell lines: modulation with the novel platinuma nalogue (1R, 2R-diaminocyclohexane)(trans-diacetato) (dichloro)-platinum (IV). Clin Cancer Res 1999, 5:655-663.

19. Sherr CJ, Roberts JM: CDK inhibitors: positive and negative regulators of G1-phase progression. Genes Dev 1999, 13:1501-1512.

20. Taylor WR, Stark GR: Regulation of the G2/M transition by p53. Oncogene 2001, 20:1803-1815.

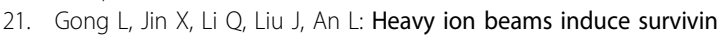
expression in human hepatoma SMMC-7721 cells more effectively than X-rays. Acta Biochim Biophys Sin (shanghai) 2007, 39:575-582.

22. Fan H, Zhao ZJ, Cheng YC, Shan YF, Lu ZH, Zhang JQ, Xie W: Gene induction and apoptosis in human hepatocellular carcinoma cells SMMC-7721 exposed to 5-aza-2'-deoxycytidine. Chin Med J (Engl) 2007, 120:1626-1631.

23. Harstrick A, Bokemeyer C, Schamofkse M, Hapke G, Reile D, Schmoll HJ: Preclinical activity of a new platinum analogue, lobaplatin, in cisplatinsensitive and -resistant human testicular, ovarian, and gastric carcinoma cell lines. Cancer Chemother Pharmacol 1993, 33:43-47.

24. Saris CP, van de Vaart PJ, Rietbroek RC, Blommaert FA: In vitro formation of DNA adducts by cisplatin, lobaplatin, and oxaliplatin in calf thymus DNA in solution and in cultured human cells. Carcinogenesis 1996, 17:2763-2769

25. Sorenson CM, Eastman A: Influence of cis-diamminedichloroplatinum(II) on DNA synthesis and cell cycle progression in excision repair proficient and deficient Chinese hamster ovary cells. Cancer Res 1988, 48:6703-6707.

26. Ormerod MG, Orr RM, Peacock JH: The role of apoptosis in cell killing by ciplatin: a flow cytometric study. Br J Cancer 1994, 69:93-100.

27. Nishio K, Fujiwara Y, Miyahara Y, Takeda Y, Ohira T, Kubota N, Ohta S, Funayama $\mathrm{Y}$, Ogasawara $\mathrm{H}$, Ohata M: cis-Diamminedichloroplatinum(II) inhibits p34cdc2 protein kinase in human lung-cancer cells. Int J Cancer 1993, 55:616-622.

28. Voland C, Bord A, Péleraux A, Pénarier G, Carrière D, Galiègue S, Cvitkovic E, Jbilo O, Casellas P: Repression of cell cycle-related proteins by oxaliplatin but not cisplatin in human colon cancer cells. Mol Cancer Ther 2006, 5:2149-2157.

doi:10.1186/1756-8722-3-43

Cite this article as: Wu et al:: Lobaplatin arrests cell cycle progression in human hepatocellular carcinoma cells. Journal of Hematology \& Oncology 2010 3:43.

\section{Submit your next manuscript to BioMed Central and take full advantage of:}

- Convenient online submission

- Thorough peer review

- No space constraints or color figure charges

- Immediate publication on acceptance

- Inclusion in PubMed, CAS, Scopus and Google Scholar

- Research which is freely available for redistribution

Submit your manuscript at www.biomedcentral.com/submit
Biomed Central 